\title{
ANALISIS RENCANA PELAKSANAAN PEMBELAJARAN (RPP) GURU BAHASA INDONESIA SMA NEGERI 7 MEDAN TAHUN PEMBELAJARAN 2016/2017
}

\author{
Oleh \\ Mei Anggriani Aruan \\ Fitriani Lubis, S.Pd., M.Pd.
}

\begin{abstract}
Penelitian ini bertujuan untuk mengetahui hasil analisis dokumen Rencana Pelaksanaan Pembelajaran (RPP) Guru Bahasa Indonesia SMA Negeri 7 Medan Tahun Pembelajaran 2016/2017. Penelitian ini menggunakan sumber data yaitu sebanyak 9 RPP guru Bahasa Indonesia dengan Metode Penelitian Deskriptif Kualitatif. Instrumen yang digunakan adalah peneliti sendiri, tabel kelengkapan komponen, sistematika penyusunan komponen RPP dan Pedoman Penelahaan RPP. Hasil penelitian menunjukkan bahwa komponen RPP yang dibuat oleh guru Bahasa Indonesia SMA Negeri 7 Medan berdasarkan kelengkapan komponen dan sistematika penyusunan komponen RPP, yaitu. Kelas X berskor $(80,87)$ kategori sesuai namun penyusunan RPP belum berdasarkan pada Permendikbud No. 22 Tahun 2016 melainkan Permendikbud No. 103 Tahun 2014, guru kelas XI berskor $(90,90)$ kategori sangat sesuai dan RPP guru kelas XII berskor $(98,86)$ kategori sangat sesuai namun RPP kelas XI dan XII penyusunan RPP masih berdasarkan pada Permendikbud No. 103 Tahun 2014. Berdasarkan analisis kesesuaian KD yang tertera pada RPP guru dapat disimpulkan bahwa RPP kelas X sudah berdasarkan Kurikulum 2013 Revisi, RPP kelas XI dan XII masih berdasarkan Kurikulum 2013. Hasil analisis isi RPP berdasarkan tabel Pedoman Penelahaan RPP maka diperoleh hasil analisis RPP guru kelas X berada pada nilai (64,44\%) kategori cukup sesuai Kurikulum 2013 Revisi, kelas XI $(78,2 \%)$ dan kelas XII $(84,51 \%)$ kedua RPP berada pada kategori sesuai terhadap kurikulum 2013.
\end{abstract}

\section{Kata kunci : RPP, Kurikulum 2013, Bahasa Indonesia}

\section{PENDAHULUAN}

Upaya memperbaiki serta meningkatkan mutu pendidikan seakan tak ada habisnya. Banyak agenda reformasi yang telah, sedang diupayakan, dan akan dilaksanakan. Kurikulum di tahun 2000an yakni, KBK (Kurikulum Berbasis Kompetensi) 2004, KTSP (Kurikulum Tingkat Satuan Pendidikan), dan Kurikulum 2013, adalah kurikulum yang berbasis pada kompetensi (competency based) dengan pembelajaran yang bersifat konstruktivisik dimana guru berperan sebagai fasilitator selama proses pembelajaran. Terlaksananya kurikulum pada pembelajaran bukan hanya tugas pemerintah dan kepala sekolah, keprofesionalan guru juga menjadi andil untuk mengembangkan perangkat pembelajaran, yakni pengembangan silabus, 
buku ajar, sumber dan media pembelajaran, model pembelajaran, instrumen asesmen, dan RPP. Perangkat pembelajaran tersebut perlu diimplementasikan dalam praktik pembelajaran sehari-hari.

Setiap guru mata pelajaran pada satuan pendidikan diwajibkan menyusun RPP di mana RPP disusun guru dengan mengacu pada silabus, namun demikian masih banyak guru yang tidak menyusun RPP yang menjadikan kekhwatiran kalau guru tidak dapat mencapai tujuan pembelajaran yang maksimal, seperti yang dikemukakan oleh Joseph dan Leonard (Majid, 2009:95) bahwa: "Teaching without adequate written planning is sloppy and almost always ineffective, because the teacher has not thought out exactly what to do and how to do it." Agar guru dapat membuat persiapan mengajar yang efektif dan berhasil guna, maka guru dituntut untuk memahami berbagai aspek yang berkaitan dengan perkembangan persiapan mengajar, baik yang berkaitan dengan hakikat, fungsi, prinsip maupun prosedur pengembangan persiapan mengajar, serta mengukur efektifitas mengajar.

Pembelajaran harus memiliki dampak dan tujuan keberhasilan, oleh karena itu seorang guru harus merencanakan setiap pembelajaran dan membuat perencanaan tersebut. Perencanaan pembelajaran merupakan peran penting dalam memandu guru melaksanakan tugas sebagai seorang pendidik. Untuk membuat perencanaan yang baik dan dapat menyelengarakan proses pembelajaran yang ideal, maka setiap guru harus mengetahui unsurunsur perencanaan pembelajaran tersebut. Menurut Hunt (Majid, 2009:94) unsur-unsur pembelajaran yang baik, antara lain: mengidentifikasi kebutuhan siswa, tujuan yang kiranya hendak dicapai, berbagai strategi dan skenario yang relevan digunakan untuk mencapai tujuan, dan kriteria evaluasi. Menurut Gagne dan Briggs dalam Majid (2009:96) Rencana Pembelajaran yang baik hendaknya mengandung tiga komponen yang disebut anchor point, yaitu: 1) tujuan pengajaran; 2) materi pelajaran/bahan ajar, pendekatan dan metode mengajar, media pengajaran dan pengalaman belajar; dan 3) evaluasi keberhasilan.

Menurut Permendikbud No. 22 Tahun 2016 dan Permendikbud No. 65 tahun 2013 tentang Standar Proses Pendidikan Dasar dan Menengah, Rencana Pelaksanaan Pembelajaran (RPP) adalah rencana kegiatan pembelajaran yang dirancang tiap tatap muka untuk satu pertemuan atau lebih. Menurut Muslich (2007:45) Rencana Pelaksanaan Pembelajaran adalah rancangan pembelajaran mata pelajaran perunit yang akan ditetapkan guru dalam pembelajaran dikelas. Pengembangan RPP sebaiknya dilakukan pada setiap awal semester atau awal tahun pelajaran dengan maksud agar RPP telah tersedia terlebih dahulu dalam setiap awal pelaksanaan pembelajaran (Permendikbud No. 81A). 
Untuk menyusun RPP guru harus mengacu pada suatu KD tertentu di dalam kurikulum/silabus. RPP dibuat dalam rangka pedoman guru. Terdapat berbagai prinsip dalam menyusun RPP adalah sebagai berikut. Adapun Prinsip Penyusunan RPP 2013 Edisi Revisi menurut (Permendikbud No. 22 Tahun 2016) prinsip penyusunan RPP adalah sebagai berikut. 1)Memperhatikan perbedaan individual setiap peserta didik, diantaranya kemampuan awal, tingkat intelektual,bakat, potensi, minat motivasi belajar, kebutuhan khusus, kecepatan belajar, latar belakang budaya, norma, nilai, dan lingkungan tempat peserta didik. 2) Partisipasi aktif peserta didik. 3) Berpusat pada peserta didik untuk mendorong semangat belajar, motivasi, minat, kreativitas, inisiatif, inspirasi, inovasi dan kemandirian. 4) Pengembangan budaya membaca dan menulis yang dirancang untuk mengembangkan kegemaran membaca, pemahaman beragam bacaan, dan berekspresi dalam berbagai bentuk tulisan. 5) Pemberian umpan balik dan tindak lanjut RPP memuat rancangan program pemberian umpan balik positif, penguatan, pengayaan, dan remedi. 6) Penekanan pada keterkaitan dan keterpaduan antara KD, materi pembelajaran, kegiatan pembelajaran, indikator pencapaian kompetensi, penilaian, dan sumber belajar dalam satu keutuhan pengalaman belajar. 7) Mengakomodasi pembelajaran tematik-terpadu,keterpaduan lintas mata pelajaran, lintas aspek belajar, dan keragaman budaya. 8) Penerapan teknologi informasi dan komunikasi secara terintegrasi, sistematis, dan efektif sesuai dengan situasi dan kondisi.

Prinsip pengembangan RPP Kurikulum 2013 menurut buku Fadillah Terbitan tahun 2014 dijelaskan bahwa 1) RPP disusun guru sebagai terjemahan dari ide kurikulum dan berdasarkan silabus, 2) RPP dikembangkan guru dengan menyesuaikan apa yang dinyatakan dalam silabus dengan kondisi di satuan pendidikan, 3) Mendorong partisipasi aktif peserta didik, 4) Sesuai dengan tujuan Kurikulum 2013 untuk menghasilkan peserta didik yang mandiri dan tak berhenti belajar, 5) Mengembangkan budaya membaca dan menulis, 6) Proses pembelajaran dalam RPP dirancang dengan tujuan mengembangkan kegemaran membaca, 7) Memberikan umpan balik serta tindak lanjut, 8) RPP memuat rancangan program pemberian umpan balik positif, 9) Keterkaitan dan keterpaduan KI dan KD, materi pembelajaran, kegiatan pembelajaran, penilaian, sumber belajar dalam satu keutuhn pengalaman belajar, 10) RPP disusun dengan mempertimbangkan penerapan teknologi informasi dan komunikasi.

Menurut Permendikbud No. 81A tahun 2013 ada beberapa langkah dalam penyusunan RPP diantaranya, 1) mengkaji Silabus, 2) mengidentifikasi materi pelajaran, 3) menentukan tujuan pembelajaran, 4) mengembangkan kegiatan pembelajaran, 5) penjabaran jenis penilaian, 6) menentukan alokasi waktu, 7) menentukan sumber belajar. Menurut 
(Permendikbud No. 22) Rencana Pelaksanaan Pembelajaran (RPP) meliputi komponenkomponen, identitas sekolah, identitas mata pelajaran, kelas/semester, materi pokok, alokasi waktu, tujuan pembelajaran, kompetensi dasar, indikator, materi pembelajaran, metode pembelajaran, media pembelajaran, sumber belajar, langkah-langkah pembelajaran, penilaian hasil belajar.

Pada implementasi Kurikulum 2013 dilakukan revisi terhadap Kompetensi Dasar. Kurikulum 2013 merupakan kurikulum baru yang mulai diterapkan pada tahun pembelajaran 2013/2014. Seperti yang diketahui bahwa Kurikulum 2013 merupakan pengembangan terhadap kurikulum yang digunakan sebelumnya, baik Kurikulum Berbasis Kompetensi yang dirilis tahun 2004 dan Kurikulum Tingkat Satuan Pendidikan pada tahun 2006 (Fadillah,2014:31). Keberhasilan kurikulum 2013 tidak bisa terlepas dari peran guru sebagai ujung tombak pendidikan. Namun, kesiapan guru menghadapi tantangan kurikulum baru ini perlu menjadi perhatian. Perbaikan mutu pendidikan ini dengan demikian sesungguhnya tergantung pada kualitas guru di mana murid mengalaminya sebagai bagian dari kehidupannya sehari-hari, bukan sekedar menjelang ujian.

Menurut Dageng pembelajaran adalah suatu upaya dimana upaya tersebut bertujuan untuk membelajarkan siswa (Husamah dan Yanur, 2013). Dimana dalam pembelajaran terdapat kegiatan memilih, menetapkan, mengembangkan metode untuk mencapai hasil pengajaran yang ada, kegiatan ini termasuk inti dari suatu perencanaan pembelajaran. Tujuan dari pembelajaran itu sendiri untuk tercapainya perubahan perilaku siswa setelah mengikuti suatu pembelajaran. Dengan demikian dapat disimpulkan bahwa pembelajaran Bahasa Indonesia suatu upaya yang dilakukan oleh guru Bahasa Indonesia guna membelajarkan siswa dengan tujuan tercapainya perubahan tingkah laku siswa setelah melakukan pembelajaran. Pada Kurikulum 2013 mata pelajaran Bahasa Indonesia secara umum bertujuan agar setiap peserta didik mampu mendengarkan, membaca, memirsa (viewing), berbicara, dan menulis. Kompetensi dasar dikembangkan pada tiga lingkup materi yang saling berhubungan dan saling mendukung pengembangan kompetensi pengetahuan kebahasaan dan kompetensi keterampilan berbahasa (mendengarkan, membaca, memirsa, berbicara, dan menulis) peserta didik. Kompetensi sikap secara terpadu dikembangkan melalui kompetensi pengetahuan kebahasaan dan kompetensi keterampilan berbahasa. 


\section{METODE PENELITIAN}

Metode penelitian adalah cara yang digunakan oleh peneliti dalam mengumpulkan data penelitiannya (Arikunto, 2006:160). Adapun metode yang digunakan oleh peneliti dalam penelitian ini adalah metode Deskriptif Kualitatif. Penelitian ini berusaha untuk melaporkan keadaan objek yang diteliti sesuai dengan apa adanya, yaitu menggambarkan atau mendeskripsikan tentang kondisi RPP yang digunakan oleh guru Bahasa Indonesia SMA Negeri 7 Medan. Dalam hal ini peneliti melakukan analisis kelengkapan komponen, sistematika penyusunan dan komponen isi RPP yang disusun oleh guru Bahasa Indonesia SMA Negeri 7 Medan. Teknik pengumpulan data pada penelitian ini adalah dengan melakukan analisis terhadap dokumen RPP yang digunakan guru SMA Negeri 7 Medan. analisis dokumen dilakukan dengan mempelajari dokumen-dokumen yang telah dikumpulkan. Dokumen yang dikumpulkan adalah dokumen RPP guru Bahasa Indonesia yang dijadikan pedoman pembelajaran selama semester satu Tahun Pembelajaran 2016/2017. Kemudian diambil tiga dokumen RPP setiap guru sebagai perwakilan untuk dianalisis. Dokumen RPP dapat berupa hard file maupun soft file. Cara memperolehnya dengan membangun keakraban antara peneliti dengan guru. Data yang diperoleh kemudian dianalisis berdasarkan tabel kelengkapan, sistematika, dan tabel penelahaan komponen isi RPP.

\section{HASIL PENELITIAN DAN PEMBAHASAN}

\section{Hasil Penelitian}

Berdasarkan data yang diperoleh RPP yang diamati berjumlah sembilan RPP, masingmasing guru kelas X, XI, XII diambil 3 RPP untuk dianalisis. Setelah awalnya dilakukan pemeriksaan, RPP guru kelas X, XI, XII sesuai dengan mata pelajaran Bahasa Indonesia. Kemudian diketahui dari guru bahwasanya penyusunan Komponen RPP Guru Kelas X menggunakan Permendikbud No. 22 Tahun 2016 dan Komponen RPP Guru Kelas XI dan XII berdasarkan Permendikbud No. 103 Tahun 2014. Hasil penelitian lebih lanjut mengenai kesesuaian Komponen dan Isi RPP yang diperoleh peneliti adalah sebagai berikut.

\section{Analisis Kesesuaian Komponen RPP}

Analisis Kelengkapan dan Sistematika Penyusunan Komponen RPP

Berdasarkan hasil analisis kelengkapan dan sistematika penyusunan komponen RPP menunjukkan bahwa nilai rata-rata kesesuaian komponen RPP tiap guru Bahasa SMA Negeri 7 Medan Tahun Pembelajaran 2016/2017 adalah. RPP guru kelas X berskor 80,87\% kategori sesuai dengan komponen RPP Kurikulum 2013 namun penyusunannya belum berdasarkan 
pada Permendikbud No. 22 Tahun 2016 mengenai Standar Proses dan Isi. Komponen RPP penyusunannya masih berdasarkan pada Permendikbud No. 103 tahun 2014 dikarenakan munculnya KI pada RPP dan tidak munculnya Materi Pokok dan Tujuan Pembelajaran. Komponen yang tidak sesuai tersebut disebabkan karena ketergesaan Kurikulum 2013 revisi sehingga guru tidak mengetahui ternyata KD pada implementasi K13 direvisi dan harus menggunakan Penyusunan Komponen pada Permendikbud No. 22 tahun 2016. RPP guru kelas XI berskor 90,90\% Amat Sesuai dengan komponen RPP pada Permendikbud No. 103 Tahun 2014 dan RPP benar disusun berdasarkan Permendikbud No. 103 Tahun 2014 tentang Pembelajaran pada Pendidikan Dasar dan Menengah. RPP guru kelas XII berskor 98,86 kategori amat sesuai dengan komponen RPP pada Permendikbud No. 103 Tahun 2014, dan penyusunannya benar berdasarkan Permendikbud No. 103 Tahun 2014 tentang Pembelajaran pada Pendidikan Dasar dan Menengah. Untuk hasil dari analisis kesesuaian komponen RPP dapat dilihat pada tabel dan bagan berikut.

Tabel 4.4

Skor Akhir Analisis Kesesuaian Komponen RPP

\begin{tabular}{|l|c|c|c|c|}
\hline No. & RPP Guru & $\begin{array}{c}\text { Kelengkapan } \\
\text { Komponen }\end{array}$ & $\begin{array}{c}\text { Sistematika } \\
\text { Komponen }\end{array}$ & Rata-Rata \\
\hline 1. & Kelas X & $88,23 \%$ & $73,52 \%$ & $80,87 \%$ Sesuai \\
\hline 2. & Kelas XI & $100 \%$ & $81,81 \%$ & $90,90 \%$ Sangat sesuai \\
\hline 3. & Kelas XII & $100 \%$ & $97,72 \%$ & $98,86 \%$ Sangat sesuai \\
\hline
\end{tabular}

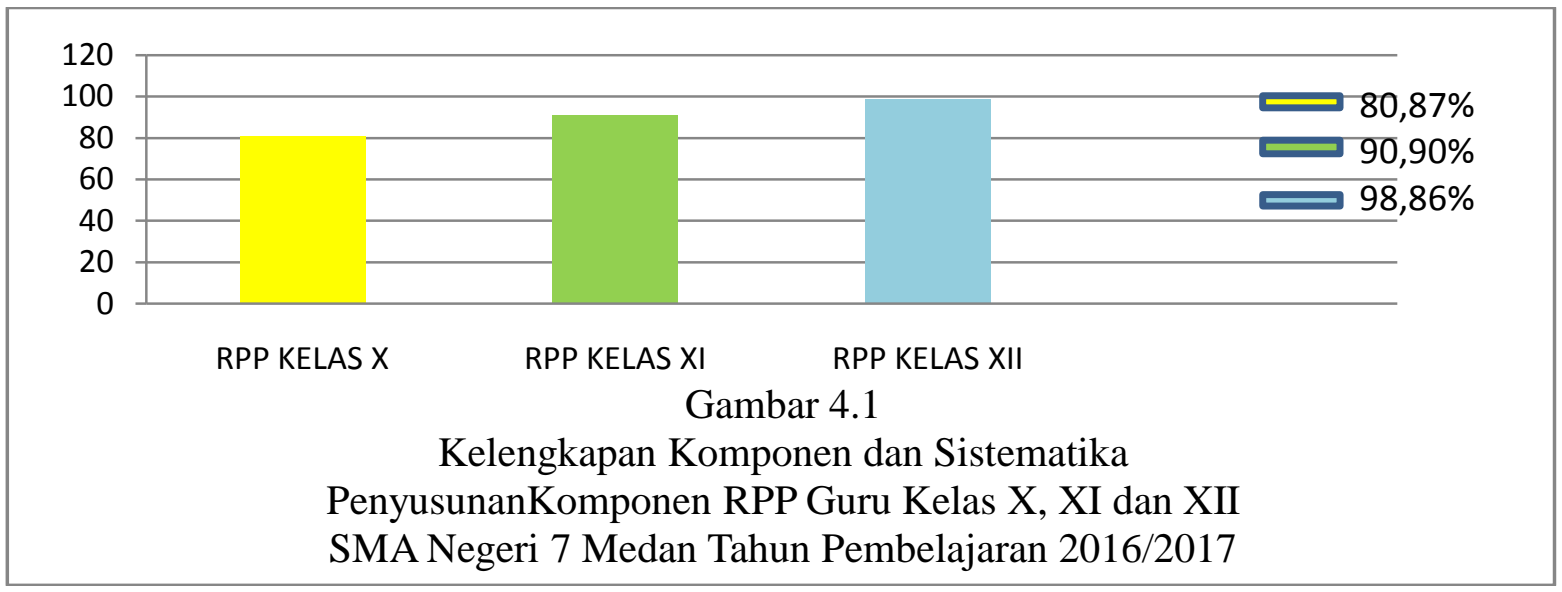

\section{Analisis Kesesuaian Isi RPP}

\section{a. Analisis Teks pada KD RPP Guru}

Dari hasil analisis kesesuaian teks pada KD diperoleh hasil bahwasanya teks pada KD RPP guru kelas X sudah menggunakan KD yang direvisi sebagaimana pernyataan oleh guru bahwa RPP dinyatakan sesuai dengan Permendikbud No. 22 Tahun 2016 dan benar telah menggunakan Kurikulum 2013 revisi, sedangkan untuk hasil analisis teks pada RPP guru 
kelas XI dan XII tidak menggunakan Kurikulum 2013 revisi hal tersebut sesuai dengan pernyataan guru. Pada analisis teks untuk kelas XI dan XII peneliti menggunakan Permendikbud No. 69 tahun 2103. Dari hasil tersebut dinyatakan teks pada KD sesuai dengan Permendikbud No. 69 tahun 2013. Untuk hasil analisis dapat dilihat pada tabel berikut.

Tabel 4.5

Analisis Kesesuaian Teks Kelas X

\begin{tabular}{|c|c|c|c|c|}
\hline No. & $\begin{array}{c}\text { Materi Pokok } \\
\text { Bahasa Indonesia }\end{array}$ & KD & Jenis Teks K13 Revisi & $\begin{array}{c}\text { Kesesuaian } \\
\text { KD }\end{array}$ \\
\hline \multirow{3}{*}{1.} & \multirow{2}{*}{$\begin{array}{c}\text { Kelas X Semester } \\
\text { Ganjil }\end{array}$} & $3.1,4.1$ & Teks Laporan Hasil Observasi & Sesuai \\
\cline { 3 - 5 } & & $3.2,4.2$ & Teks Laporan Hasil Observasi & Sesuai \\
\cline { 3 - 5 } & & $3.3,4.3$ & Teks Eksposisi & Sesuai \\
\hline
\end{tabular}

(sumber Permendikbud No. 24 tahun 2016)

Tabel 4.6

Analisis Kesesuaian Teks Kelas XI dan XII

\begin{tabular}{|l|c|c|c|c|}
\hline No. & $\begin{array}{c}\text { Materi Pokok } \\
\text { Bahasa Indonesia }\end{array}$ & KD & Jenis Teks K13 Revisi & Kesesuaian KD \\
\hline \multirow{3}{*}{ 2. } & \multirow{2}{*}{$\begin{array}{c}\text { Kelas XI } \\
\text { Semester Ganjil }\end{array}$} & $3.1,4.1$ & Teks Cerita Pendek & Sesuai \\
\cline { 3 - 5 } & & $3.2,4.2$ & Teks Cerita Pendek & Sesuai \\
\cline { 3 - 5 } & $3.3,4.3$ & Teks Cerita Pendek & Sesuai \\
\hline \multirow{2}{*}{3.} & $\begin{array}{c}\text { Kelas XII } \\
\text { Semester Ganjil }\end{array}$ & $3.1,4.1$ & Teks Cerita Sejarah & Sesuai \\
\cline { 3 - 5 } & Semesuai & Teks Cerita Sejarah & Sesuai \\
\cline { 3 - 5 } & & $3.3,4.3$ & Teks Cerita Sejarah & Sesuai \\
\hline
\end{tabular}

(sumber Permendikbud No. 69 tahun 2013)

\section{b. Analisis Komponen Isi RPP}

Berdasarkan hasil analisis komponen isi diketahui bahwa RPP yang disusun guru kelas X $(64,44)$ kategori cukup sesuai karena skor <75, kelas XI $(78,2)$ dan kelas XII $(84,51)$ kategori "sesuai", karena skor $<90$. Namun diperoleh hasil bahwa penyusunan KD pada RPP guru kelas X sudah berdasarkan pada Kurikulum 2013 Revisi sedangkan RPP milik guru kelas XI dan kelas XII belum berdasarkan pada Kurikulum 2013 Revisi. Hal tersebut diketahui setelah dilakukan penelahaan RPP terhadap teks pada KD yang disusun oleh guru. Berdasarkan pedoman penelaahan RPP disajikan hasil data dalam bentuk tabel dan bagan berikut.

Tabel 4.7

Presentase Kesesuaian Komponen Isi

RPP Guru Bahasa Indonesia SMA Negeri 7 Medan

\begin{tabular}{|r|c|c|c|c|}
\hline NO. & RPP & Frekuensi & Presentase & Rata-rata Nilai RPP \\
\hline \multirow{3}{*}{1.} & Kelas X & & & \multirow{2}{*}{ 64,44\% Cukup sesuai } \\
\cline { 2 - 4 } & RPP 1 & 58 & 64,44 & \\
\cline { 2 - 4 } & RPP 2 & 58 & 61,11 & \\
\hline
\end{tabular}




\begin{tabular}{|l|c|c|c|c|}
\hline & RPP 3 & 62 & 67,77 & \multirow{2}{*}{} \\
\hline \multirow{4}{*}{2.} & Kelas XI & & & \multirow{2}{*}{$78,2 \%$ Sesuai } \\
\cline { 2 - 4 } & RPP 1 & 65 & 83,33 & \\
\cline { 2 - 4 } & RPP 2 & 62 & 79,48 & \multirow{2}{*}{ 84,51\% Sesuai } \\
\cline { 2 - 4 } & RPP 3 & 56 & 71,79 & \\
\hline \multirow{4}{*}{3.} & Kelas XII & & & \\
\cline { 2 - 4 } & RPP 1 & 67 & 85,89 & \\
\cline { 2 - 4 } & RPP 2 & 66 & 84,61 & \\
\cline { 2 - 4 } & RPP 3 & 65 & 83,33 & \\
\hline
\end{tabular}

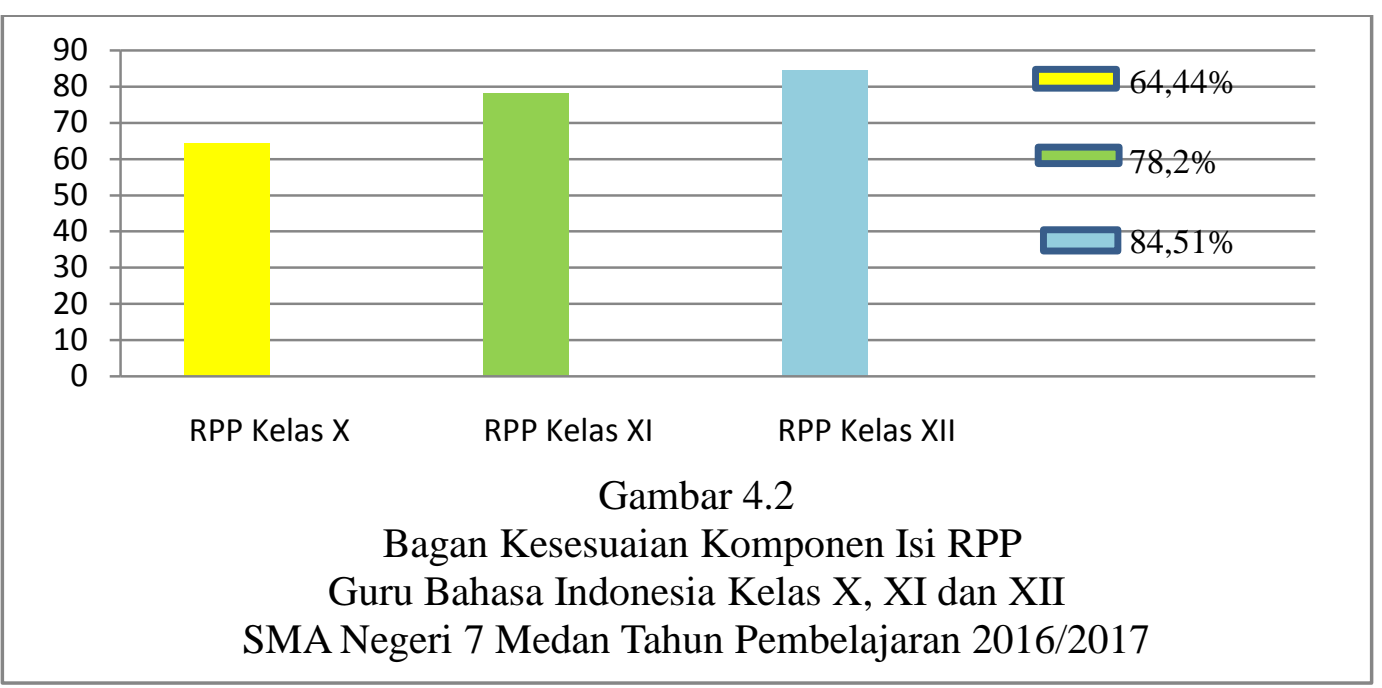

\section{Pembahasan Hasil Penelitian}

Pada bagian pembahasan akan diuraikan dua aspek pokok yaitu kesesuaian komponen terhadap Permendikbud No. 22 Tahun 2016 dan Permendikbud No. 103 Tahun 2014 dan komponen isi RPP guru Bahasa Indonesia SMA Negeri 7 Medan dengan cara menganalisis kelengkapan dan sistematika penyusunan komponen RPP serta menganalisis kesesuaian isi RPP guru Bahasa Indonesia SMA Negeri 7 Medan berdasarkan aturan penyusunannya baik dari prinsip, kelengkapan dan penulisannya dengan menggunakan pedoman penelahaan RPP untuk implementasi Kurikulum 2013 dengan menyesuaikan Permendikbud yang digunakan guru sebagai acuan penyusunan Komponen RPP.

\section{Analisis Kesesuaian Komponen RPP} Kelengkapan Komponen dan Sistematika Penyusunan Komponen RPP

Untuk mengetahui kesesuaian komponen RPP maka peneliti melakukan analisis kelengkapan komponen dengan memberi skor 0 apabila komponen RPP tidak dimuat atau tidak sesuai dan memberikan nilai 1 untuk komponen RPP yang dimuat atau sesuai. Pada analisis Sistematika penyusunan Komponen RPP peneliti memberi penilaian 0 untuk 
komponen RPP yang tidak sesuai sama sekali sistematika ataupun penyusunan, sementara peneliti memberi nilai 1 jika komponen sistematika sesuai namun penyusunannya tidak sesuai atau penyusunannya sesuai namun sistematikanya tidak sesuai, sementara untuk komponen sesuai sistematikanya dan penyusunannya diberikan nilai 2.

Dari hasil analisis untuk kelengkapan komponen RPP yang disusun oleh guru kelas X dengan KD 3.1, 4.1, 3.2, 4.2, 3.3, 4.3. diperoleh skor RPP adalah 88,23\% dengan kategori komponen RPP sesuai dengan komponen RPP pada Kurikulum 2013. Hasil analisis juga menyatakan bahwasanya Komponen RPP yang disusun oleh guru belum berdasarkan Pada Permendikbud No. 22 Tahun 2016 diketahui dari analisis kelengkapan komponen pada RPP muncul KI 3 dan 4, sementara materi pokok dan tujuan pembelajaran tidak dimuat. Berdasarkan analisis kelengkapan komponen maka diperoleh hasil bahwasanya komponen RPP seluruhnya sesuai. Dari hasil analisis untuk kelengkapan komponen RPP yang disusun oleh guru kelas XI dengan KD 3.1, 4.1, 3.2, 4.2, 3.3, 4.3. diperoleh skor RPP adalah 100\%. Hasil analisis juga menyatakan bahwasanya Komponen RPP yang disusun oleh guru benar berdasarkan Pada Permendikbud No. 103 Tahun 2014. Dari hasil analisis untuk kelengkapan komponen RPP yang disusun oleh guru kelas XII dengan KD 3.1, 4.1, 3.2, 4.2, 3.3, 4.3. diperoleh skor RPP adalah 100\%. Hasil analisis juga menyatakan bahwasanya Komponen RPP yang disusun oleh guru benar berdasarkan Pada Permendikbud No. 103 Tahun 2014.

Dari hasil analisis sistematika penyusunan komponen RPP maka diperoleh hasil bahwa komponen RPP guru Kelas $\mathrm{X}$ belum semua penyusunan sistematikanya sesuai. Komponen yang sistematikanya tidak sesuai adalah. Materi Pokok, Alokasi waktu, Tujuan Pembelajaran, Metode, Media, Sumber dan Langkah Pembelajaran. Sementara komponen yang sesuai Identitas Sekolah, Identitas Mata Pelajaran, Kelas/semester, Kompetensi Dasar, Indikator, Materi Pembelajaran, Kegiatan Pendahuluan, Inti, Penutup, dan Penilaian. Dari hasil analisis untuk sistematika penyusunan komponen RPP yang disusun oleh guru kelas X dengan KD 3.1, 4.1, 3.2, 4.2, 3.3, 4.3. diperoleh skor RPP adalah 73,52\%. Hasil analisis juga menyatakan bahwasanya Komponen RPP yang disusun oleh guru belum berdasarkan Pada penyusunan sistematika Permendikbud No. 22 Tahun 2016 dan masih mengacu pada Permendikbud No. 103 tahun 2014. Dari hasil analisis maka diperoleh hasil bahwa komponen RPP guru Kelas XI belum seluruhnya sistematika dan penyusunannya sesuai. Komponen yang sistematikanya belum sesuai seluruhnya adalah. KD pada KI-1 hingga KI-4 dan Indikator KD pada KI-1 hingga KI-4. Komponen RPP yang sesuai diantaranya, Sekolah, Mata Pelajaran, Kelas/ Semester, Alokasi Waktu, Indikator Pencapaian Kompetensi, Materi Pembelajaran, Kegiatan Pembelajaran, Kegiatan Pendahuluan, Kegiatan Inti, Kegiatan 
Penutup, Penilaian, Media/alat, Bahan, dan Sumber Belajar. Dari hasil analisis untuk sistematika penyusunan komponen RPP yang disusun oleh guru kelas XI dengan KD 3.1, 4.1, 3.2, 4.2, 3.3, 4.3. diperoleh skor RPP adalah 81,81\%. Hasil analisis juga menyatakan bahwasanya Komponen RPP yang disusun oleh guru benar berdasarkan Pada penyusunan sistematika Permendikbud No. 103 Tahun 2014. Dari hasil analisis untuk sistematika penyusunan komponen RPP yang disusun oleh guru kelas XII dengan KD 3.1, 4.1, 3.2, 4.2, 3.3, 4.3. diperoleh skor RPP adalah 97,72\%. Hasil analisis juga menyatakan bahwasanya Komponen RPP yang disusun oleh guru benar berdasarkan Pada sistematika penyusunan Permendikbud No. 103 Tahun 2014.

Setelah didapat hasil penskoran terhadap kelengkapan komponen RPP dan Kesesuaian Sistematika penyusunan komponen RPP maka hasil yang diperoleh untuk kesesuaian komponen RPP berdasarkan pada Permendikbud No. 22 tahun 2016 dan Permendikbud No. 103 Tahun 2014. Data yang diperoleh dari hasil kelengkapan dan sistematika penyusunan komponen dijumlahkan atau dirata-ratakan kemudian disesuaikan dengan kategori tingkatannya. Hasil rata-rata tersebut adalah. RPP guru kelas X berskor 80,87\% kategori sesuai, guru kelas XI berskor 90,90\% kategori sangat sesuai dan RPP guru kelas XII berskor 98,86\% kategori sangat sesuai. Dari analisis kelengkapan dan sistematika penyusunan komponen RPP disimpulkan juga bahwasanya RPP yang disusun oleh guru kelas X belum berdasarkan pada Permendikbud No. 22 tahun 2016 melainkan pada Permendikbud No. 103 tahun 2014, sementara untuk penyusunan komponen RPP guru kelas XI, dan XII benar berdasarkan pada Permendikbud No. 103 Tahun 2014 dan dinyatakan sangat sesuai terhadap Permendikbud No. 103 Tahun 2014.

\section{Kesesuaian Komponen Isi RPP}

\section{a. Analisis Teks pada KD}

Pada analisis kesesuaian komponen isi peneliti terlebih dahulu menganalisis KD pada RPP untuk mengetahui apakah penyusunan Teks pada KD telah sesuai dengan Permendikbud pelaksana Kurikulum atau belum sesuai dan masih menggunakan KD yang belum direvisi. Diperoleh hasil bahwasanya teks pada KD RPP guru kelas X sudah direvisi, sedangkan untuk kelas XI dan XII belum menggunakan KD yang direvisi. Kemudian selanjutnya teks pada KD dianalisis kesesuaiannya terhadap Permendikbud pelaksana Kurikulum tersebut. Dalam menganalisis peneliti menggunakan sumber untuk analisis teks pada KD RPP guru kelas X menggunakan Permendikbud No. 24 Tahun 2016, sedangkan analisis teks pada KD RPP guru Kelas XI dan XII menggunakan Permendikbud No. 69 Tahun 2013. 
Dari analisis teks tersebut diperoleh hasil bahwa penyusunan teks pada KD yang tertulis di RPP guru kelas X dengan analisis mengacu pada Permendikbud No. 24 Tahun 2016 adalah KD 3.1. dan 4.1 Teks Laporan Hasil Observasi, KD 3.2 dan 4.2 adalah Teks Laporan Hasil Observasi dan KD 3.3 dan 4.3 adalah Teks Eksposisi. KD pada RPP tersebut sesuai dengan kurikulum 2013 revisi. Penyusunan teks pada KD yang tertulis di RPP guru kelas XI dengan analisis mengacu pada Permendikbud No. 69 tahun 2013 adalah KD 3.1 dan 4.1 adalah teks cerpen, KD 3.2 dan 4.2 adalah teks cerpen, KD 3.3 dan 4.3 adalah teks cerpen. Ketiga KD tersebut sesuai dengan Permendikbud No. 69 tahun 2013, teks pada KD Kurikulum 2013. Penyusunan teks pada KD yang tertulis di RPP guru kelas XII adalah KD 3.1. dan 4.1 teks Cerita Sejarah, KD 3.2 dan 4.2 adalah teks Cerita Sejarah KD 3.3 dan 4.3 Cerita Sejarah. Teks pada KD RPP guru sesuai dengan teks pada Permendikbud No. 69 tahun 2013. Penyusunan teks pada KD belum berdasarkan pada Kurikulum 2013 Revisi. Penyusunan teks pada KD masih mengacu pada Kurikulum 2013, teks yang dianalisis benar sesuai dengan Permendikbud No. 69 tahun 2013.

\section{b. Analisis Komponen Isi RPP}

Dari hasil pembahasan data analisis komponen isi RPP maka dapat disimpulkan hasil analisis RPP dalam bentuk deskripsi berikut. Pertama, seluruh RPP sudah memuat identitas sekolah. Kedua, penyusunan komponen materi pokok, sebagian RPP tidak memunculkan materi pokok dimana dalam penulisan RPP guru harus mencantumkan materi pokok dan dalam perumusan alokasi waktu seluruh RPP tidak sama dengan silabus. Ketiga, RPP kelas X tidak memuat tujuan pembelajaran. Keempat dalam penulisan alokasi waktu tidak sesuai seluruhnya dengan alokasi waktu pada silabus. Kelima KD terdapat KD yang tidak tertera dan saling link antar KD lainnya. Keenam, rumusan indikator belum sepenuhnya sesuai dengan KD, bahkan ada beberapa penggunaan kata kerja operasional dengan kompetensi pengetahuan dan keterampilan yang tidak tepat. Ketujuh, materi ajar belum sepenuhnya memuat fakta, prinsip, konsep, dan prosedur. Hal ini karena beberapa RPP hanya mencantumkan point-point singkat dari materi. Kedelapan, pada metode pembelajaran sebagian RPP yaitu RPP kelas XI dan XII tidak memuat metode, model, dan pendekatan untuk bagian point komponen. Sebagian penggunaan model pada RPP tidak sesuai dalam penerapannya. Kesembilan, media pembelajaran yang digunakan guru belum sesuai dengan materi dan pendekatan saintifik dan media yang digunakan lebih layak menjadi bahan penyampai materi. Kesepuluh sumber belajar sudah dimuat dalam RPP namun ada beberapa RPP yang tidak mencantumkan keseluruhan sumber belajar yang digunakan. Kesepuluh, langkah-langkah saintifik sudah lengkap dan telah dimunculkan dalam pelaksanaan 
pembelajaran. Langkah-langkah pembelajaran juga ada yang tidak sesuai dengan model pembelajaran. Kesebelas, rancangan penilaian belum semuanya mencerminkan penilaian autentik karena bentuk dan teknik penilaian pada sebagian RPP hanya terdiri dari yaitu tes tertulis dan unjuk kerja. Selain itu rancangan penilaian pada RPP belum semua menyertakan kunci jawaban dan pedoman penskoran. Jadi, berdasarkan hasil analisis data dengan mengacu pada pedoman penelaahan RPP, dapat disimpulkan bahwa komponen isi RPP yang dibuat oleh guru kelas X cukup sesuai dengan implementasi Kurikulum 2013 dan teks pada KD RPP sudah menggunakan Revisi, RPP kelas XI, dan XII sesuai dengan aturan penyusunan komponen berdasarkan Implementasi Kurikulum 2013.

Selanjutnya untuk analisis kontras sumber RPP untuk kelas X sesuai Permendibud No. 22 tahun 2016, sesuai Permendikbud No. 24 tahun 2016, tidak sesuai dengan Silabus yang dibuat oleh guru, sesuai dengan buku siswa dan cukup sesuai dengan PIK. Untuk analisis kontras sumber RPP untuk kelas XI sangat sesuai Permendibud No. 103 tahun 2014, sesuai Permendikbud No. 69 tahun 2013, tidak sesuai dengan Silabus yang dibuat oleh guru, sesuai dengan buku siswa dan cukup sesuai dengan PIK. Selanjutnya untuk analisis kontras sumber RPP kelas XII sangat sesuai Permendibud 103 tahun 2014, sesuai Permendikbud No. 69 tahun 2013, tidak sesuai dengan Silabus yang dibuat oleh guru, sesuai dengan buku siswa dan sesuai dengan PIK.

\section{PENUTUP}

Berdasarkan hasil penelitian yang telah diuraikan pada pembahasan, dapat diambil simpulan yaitu, RPP guru kelas X berskor 80,87 kategori sesuai, guru kelas XI berskor 90,90 kategori sangat sesuai dan RPP guru kelas XII berskor 98,86 kategori sangat sesuai. Namun perlu diketahui bahwa RPP kelas X belum disusun berdasarkan pada Permendikbud No. 22 tahun 2016 penyusunan komponen dan sistematika RPP masih mengacu pada Permendikbud No. 103 tahun 2014. Dari hasil analisis Teks pada KD maka diperoleh kesimpulan bahwa RPP kelas X sudah mengacu pada Kurikulum 2013 Revisi 2016 dan RPP kelas XI dan XII masih berdasarkan pada Kurikulum 2013. Dari hasil analisis isi komponen menggunakan penelahaan RPP maka diperoleh nilai komponen isi RPP guru Kelas X, $(64,44)$ kategori RPP cukup sesuai dengan Kurikulum 2013 Revisi. RPP guru Kelas XI bernilai $(78,2)$ RPP berada pada kategori sesuai dengan Kurikulum 2013. RPP guru Kelas XII bernilai $(84,51)$, RPP berada pada kategori sesuai sesuai dengan Kurikulum 2013. 


\section{DAFTAR PUSTAKA}

Arikunto, S. 2006. Prosedur Penelitian Suatu Pendekatan Praktik. Jakarta: Rineka Cipta.

Fadlillah. 2014. Implementasi Kurikulum 2013. Yogyakarta: Ar-Ruzz Media.

Husamah, \& Yanur. 2013. Desain Pembelajaran Berbasis Pencapaian Kompetensi Panduan Merancang Pembelajaran untuk Mendukung Implementasi Kurikulum 2013. Jakarta: Prestai Pustakaraya.

Majid, Abdul. 2009. Perencanaan Pembelajaran (Mengembangkan Standar Kompetensi Guru). Bandung: PT Remaja Rosdakarya.

Peraturan Menteri Pendidikan dan Kebudayaan Nomor 65 Tahun 2013 Tentang Standar Proses Pendidikan Dasar dan Menengah.

Nomor 69 Tahun 2013 Tentang Kerangka Dasar dan Struktur Kurikulum Sekolah Menengah Atas/Madrasah Aliyah.

. Nomor 81 A tahun 2013 Tentang Implementasi Kurikulum.

. No. 22 Tahun 2016 Tentang Standar Proses Pendidikan Dasar dan Menengah.

. No. 24 Tahun 2016 Tentang Kompetensi Inti dan Kompetensi Dasar Pada Pelajaran Pada Kurikulum 2013.

Salinan Lampiran Peraturan Menteri Pendidikan dan Kebudayaan RI. No. 103 Tahun 2014. Pedoman Pelaksanaan Pembelajaran Pada Pendidikan Dasar dan Pendidikan Menengah. 